\title{
RICE - FIELD WEEDS IN THE COLOMBO AND GAMPAHA DISTRICTS OF SRI LANKA
}

\author{
J. P. N. R. CHANDR ASENA \\ Department of Botany, University of Colombo, P.O.Box 1490, \\ Colombo 7, Sri Lanka.
}

(Date of receipt : 18 May 1987)

(Date of acceptance : 31 August 1987)

\begin{abstract}
Two rice-growing districts in the low-country Wet Zone were surveyed for the wced-flora in the rice-fields. A comprehensive list of the species, including grass, sedge and broad-leaved weeds found in the rice-field's surveyed, is presented. An estimation of the frequency of occurrence of the major weeds was made in order to evaluate the abundance of the species in the rice agroecosystem. A method of scoring based on visual estimation of cover was used to evaluate the level of infestation of the wecds. litmbristylis miliacea, Isachne globosa and Cyperus iria were the most abundant monocotyledonous weed species found in the rice-fields of the two districts. Among the broad-leaved weeds, Ludwigia byssopifolia was by far the most abundant species with high levels of infestation in most of the fields surveyed. A second species of l.udwigia, yet unidentified and probably a relatively new weed record for Sri Lanka, was also found to occur in high frequency in the Colombo district. The survey revealed that a rich weed-flora occurs, both within the rice-field habitat and on the raised earthen bunds in the areas studied.
\end{abstract}

\section{Introduction}

Rice-cultivation in Sri Lanka covers an area of about 0.53 million hectares and provides employment for a very large section of the peasantry in the country. Recent times have seen an encouraging and steady increase in rice production in the country. However, weed problems are one of the major factors depressing rice yields in many parts of the island. 3,9 Total yield losses in rice due to weeds have been estimated at about $20 \%,{ }^{9}$ but this figure is dependent on factors such as type of rice cultivar, time of cultiva. tion, degree of available moisture in soil and the composition of the weed flora.

It has been reported that there are about 70-80 weed species which occur commonly as rice-field weeds, ${ }^{9}$ but that most of them cause little concern to the farmer. The number of species that comprise the major portion of the weed flora in any rice-field in the country may not exceed $10-15$, out of which only $4-5$ may be categorized as important to warrant control measures.

Many of the rice-field weeds of Sri Lanka and their distribution ${ }^{6,8}$ and weeds found in arable soils which include many of the rice-field weeds 
listed under wetland cônditions, ${ }^{2}$ have been aiready described. A more comprehensive survey of rice-field weeds in the island based on visits to 518 villages both in the Wet and Dry zones in 1975/1976 revealed that Fimbristylis miliacea (L.) Vahl, Isachne globosa (Thunb.) O.Ktze. and Cyperis haspan L. were the most serious rice-field weeds in the country. ${ }^{10}$

The present survey was carried out to update and improve the status of knowledge regarding rice-field weeds of Sri Lanka, in the Low Country Wet Zone. In addition to compiling a list of the species in accordance with the newly revised flora of the island, ${ }^{5}$ emphasis was placed on determining their frequency of occurrence and levels of infestation.

\section{Materials and Methods}

Two major rice-producing districts in the low-country Wet Zone, namely Colombo and Gampaha (Figure 1), were chosen for the present survey, which was carried out during the 'Yala' (April-August) season of 1984. The sampled rice fields were the same ones selected by the Department of Census and Statistics for their annual rice-yield estimations, ${ }^{7}$ done every season at District level. The Department of Census and Statistics uses a multi-stage stratified sampling frame for the purpose of selecting rice-fields for sampling. ${ }^{7}$ Villages are selected at random with probability proportional to the area under rice cultivation. In each selected village, two rice-fields are chosen at random and in each one, a. 'Liyadde' (an area surrounded by elevated earthen banks) is also chosen at random. Rice-yield estimations are done by harvesting experimental plots of a standard size located within the selected 'liyaddes'. The present rice-weed survey was also done in the same randomly chosen fields and in many instances incorporating the 'liyaddes' selected for yield estimations by the Department of Census and Statistics. In each of the chosen rice-fields a minimum of 4 liyaddes was surveyed.

Each sample field was surveyed by walking along the bunds, collecting and identifying the weeds present and recording their occurrence. Quadrats of $0.5 \mathrm{~m}^{2}$ were placed at random, a minimum of 4 times within a liyadde, to study the weeds that were occurring below the crop canopy. The weeds growing above the crop canopy were evaluated by scanning the whole field/ lixadde. The bund-weed flora was also studied using the quadrats. The relative abundance of each species was scored using the following key: $0=$ weed species not observed; $1=$ a few scattered plants; $2=$ occasional patches of the weed; $3=$ weed widespread throughout field (or bund) $; 4=$ a dense infestation, and $5=$ weed completely dominating and masking the crop (or other on bunds). Categories 2,3,4 and 5 corresponded approximately with $1-25 \%$ weed cover, $26-50 \%$ weed cover, $51-75 \%$ weed cover and $76-100 \%$ weed cover, respectively, based on visual estimates. Whilst the 


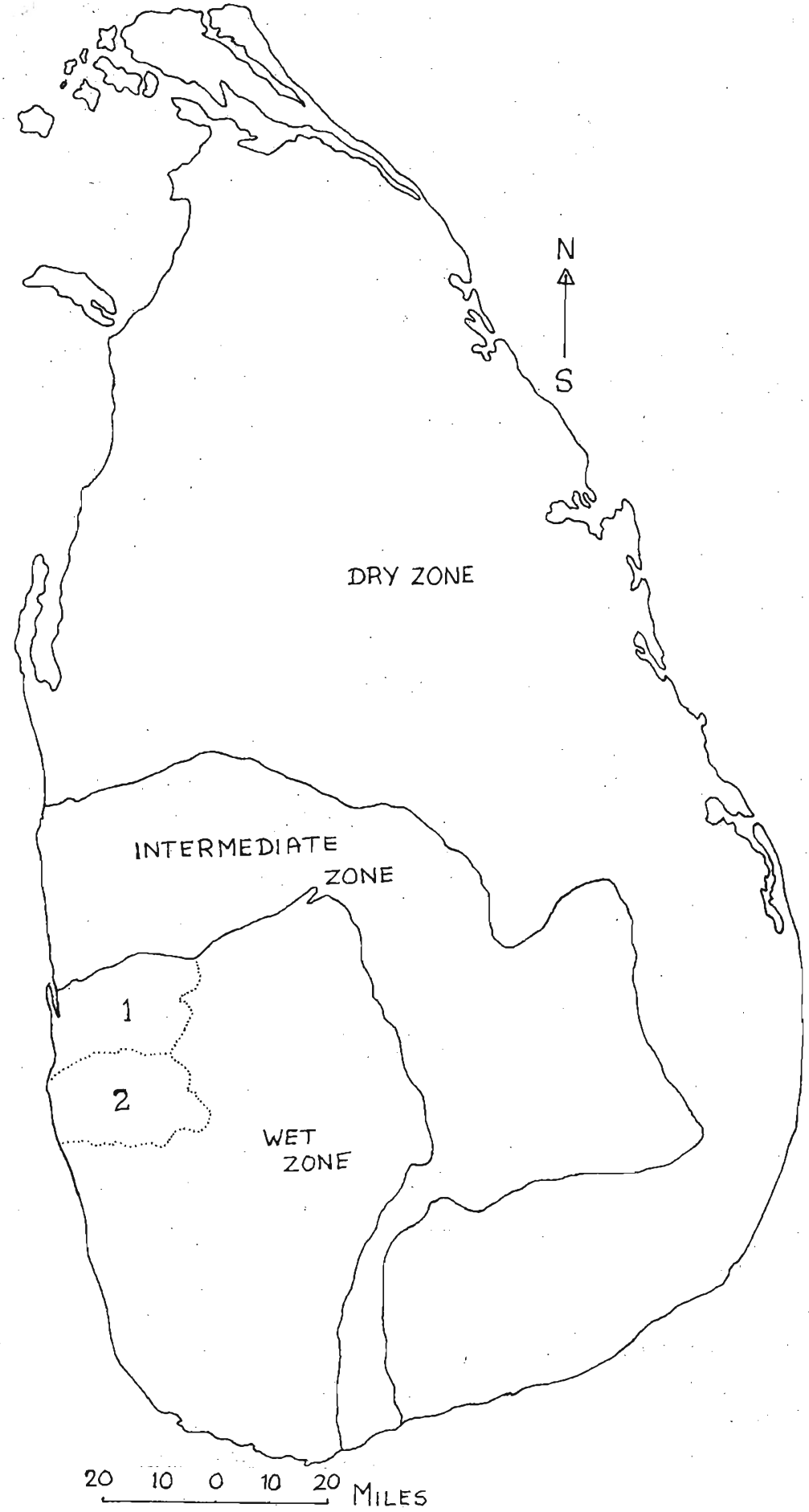

Figure 1. A Map of Sri Lanka indicating the Wet, Intermediate and Dry Zones and the Gampaha (1) and Colombo (2) districts. 
main emphasis was to record and assess the weed flora within fields/liyaddes and their bunds, some weeds frequently found associated with the network of irrigation ditches (canals) were also recorded. Weed specimens were collected as vouchers for preservation, as well as for confirmation of identity. Wherever possible the farmers who had cultivated the sampled ricefields were interviewed regarding the major weed problems they had, and the present status of such weeds.

The number of villages from each district where sampled rice-fields were located depended on the proportion of land cultivated with rice. For the 1984 Yala season when the survey was undertaken, 116 villages from the Gampaha district and 46 villages from the Colombo district were chosen by the Department of Census and Statistics for crop-yield estimations, as well by the author for the rice-weed survey. However, heavy monsoonal rains which occurred in May-June 1984 destroyed a large number of fields which had been sown. This reduced the number villages surveyed in the present work to 88 from the Gampaha district (176 fields) and 40 from the Colombo district ( 80 fields).

\section{Results and Discussion}

Table 1 provides a comprehensive list of the species of rice-field weeds found in the two districts. The major families to which the commonest rice-field weeds belong were: Gramineae (29 spp.), Cyperaceae (31 spp.) and Scrophulariaceae (12 spp.). The families Asteraceae (7 spp.), Leguminosae (9 spp.) and Onagraceae (4 spp.) were also well represented within the rice-field habitats, and on the bunds.

Table 1. Floristic composition of rice-field weeds in Gampaha and Colombo districts, indicating their occurrence and major habitat in the rice-agroecosystem (Yala season, 1984).

Taxon \& Family

Occurrence $^{\mathrm{a}}$

Major

Habitat ${ }^{b}$

1. ACANTHACEAE

Asteracantba longifolia (I.) Nees

Hygropbylla salicifolia (Vahl) Nees

2. AIZOACEAE

Mollugo oppositifolia L. occasional

occasional

B

B

occasional

B 
Taxon \& Family

Occurrence $^{\mathrm{a}}$

Major

Habitat ${ }^{b}$

3. AMARANTHACEAE

Alternanthera sessilis (L.) DC.

frequent

$\mathrm{B}, \mathrm{F}$

4. BUTOMACEAF,

Limnocharis flava (L.) Buchen.

widespread

F, B, D

5. CERATOPHYLLACEAl:

Ceratophyllum demersum $\mathrm{L}$.

occasional

$\mathrm{F}, \mathrm{B}$

6. COMMELINACEAE

Commelina bengbalensis $\mathrm{L}$.

Commelina diffusa Burm. f.

$\begin{array}{ll}\text { frequent } & B . \\ \text { widespread } & B, F, D\end{array}$

7. COMPOSITAE (ASTERACEAE)

Ageratum conyzoides L.

Eclipta prostrata (L.) L.

frequent

B

Epaltes divaricata (L.) Cass.

widesprcad

$\mathrm{B}, \mathrm{F}$

occasional

B

Sphacranthus africanus $\mathrm{L}$.

frequent

$\mathrm{B}, \mathrm{F}$

Spbaerantbus indicus L.

frequent

$B, F$

Spilantbes paniculata Wall. ex DC.

occasional

$\mathrm{B}$

Vernonia cinerea (L.) Less

widespread

$B, D$

8. CONVOLVULACEAE

Ipomoea aquatica Forsk.

Ipomoea triloba L.

frequent

B,D

frequent

$\mathrm{B}, \mathrm{F}$

9. CYPERACEAE

Cyperus compressus L.

Cyperus difformis $\mathrm{L}$.

Cyperus haspan L.

Cyperus iricr $\mathrm{L}$.

Cyperus pilosus Vahl

Cyperus procerus Rottb.

Cyperus spbacelatus Rottb.

Eleocharis dulcis (Burm. f.) Trin ex. Hensch

Fimbristylis acuminata Vahl

Fimbristylis dicbotoma (L.) Vahl

Fimbristylis ferruginea (L.) Vahl

Fimbristylis umbellaris (Lam.) Vahl

$\begin{array}{ll}\text { frequent } & \text { B } \\ \text { occasional } & \text { F,B } \\ \text { widespread } & \text { F,B,D } \\ \text { widespread } & \text { F,B,D } \\ \text { widespread } & \text { F,B,D } \\ \text { frequent } & \text { B } \\ \text { frequent } & \text { B } \\ \text { widespread } & \text { F } \\ \text { widespread } & \text { B,F } \\ \text { widespread } & \text { B,F } \\ \text { widespread } & \text { B } \\ \text { occasional } & \text { B,F }\end{array}$




\begin{tabular}{|c|c|c|}
\hline Tax on \& Family & Occurrence ${ }^{\mathrm{a}}$ & $\begin{array}{l}\text { Major } \\
\text { Habitat }\end{array}$ \\
\hline Fimbristylis miliacea (L.) Vahl & widespread & $F, B, D$ \\
\hline Fimbristylis schoenoides (Retz.) Vahl & widespread & $\mathrm{B}, \mathrm{F}$ \\
\hline Fimbristylis tetragona $\mathrm{R} . \mathrm{Br}$ & widespread & $\mathrm{B}, \mathrm{F}, \mathrm{D}$ \\
\hline Fuirena ciliaris (L.) Roxb. & occasional & $\mathrm{B}, \mathrm{F}$ \\
\hline Fuirena umbellata Rottb. & widespread & $\mathrm{F}, \mathrm{B}$ \\
\hline Fuirena capitata (Burm.f.) T. Koyama & widespread & $\mathrm{B}, \mathrm{F}$ \\
\hline Kyllinga brevifolia Rottb. & widespread & $\mathrm{B}, \mathrm{F}, \mathrm{D}$. \\
\hline Kyllinga melanosperma Nees & occasional & $\mathrm{B}, \mathrm{D}$ \\
\hline Kyllinga nemoralis (J.R. \& G. Forst.) & & \\
\hline Dandy ex Hutchinson \& Dalziel & occasional & $\mathrm{B}, \mathrm{D}$ \\
\hline Kyllinga bulbosa Rottb. & widespread & B \\
\hline Mariscus paniceus (Rottb.) Vahl & occasional & B \\
\hline Pycreus polystacbyos (Rottb) Beauv. & frequent & B \\
\hline Pycreus pumilus (L.) Nees & occasional & B \\
\hline Rbynchospora corymbosa (L.) Britton & occasional. & $\mathrm{B}, \mathrm{D}, \mathrm{F}$ \\
\hline Scboenoplectus articulatus (L.) Palla & occasional & $F$ \\
\hline Schoenoplectus juncoides (Roxb.) Palla & widespread & $\mathrm{F}, \mathrm{B}, \mathrm{D}$ \\
\hline Schoenoplectus grossus (L.f.) Palla & frequent & $\mathrm{F}, \mathrm{B}, \mathrm{D}$ \\
\hline Scleria poaeformis Retz. & occasional & $\mathrm{B}, \mathrm{F}$ \\
\hline Scleria sumatrensis Retz. & occasional & $\mathrm{B}$ \\
\hline
\end{tabular}

\section{ERIOCAULACEAE}

Eriocaulon quinquangulare $\mathrm{L}$.

Eriocaulon sexangulare L.

Eriocaulon thwaitsii Koern.

widespread $\mathrm{F}$

widespread $\mathrm{F}$

frequent $F$

\section{EUPHORBIACEAE}

Euphorbia birta L.

Pbyllanthus debilis Klein ex Willd.

Pbyllantbus urinaria L.

frequent

frequent

B.

frequent

F, B

B

\section{FABACEAE (LEGUMINOSAE)}

Aeschynomene aspera $\mathrm{L}$.

Aeschynomene indica $\mathrm{L}$.

Alyssicarpus vaginalis DC.

Cassia tora L.

Desmodium beterocarpum (L.) DC.

Desmodium beterophyllum (Willd.) DC.

Desmodium triflorum (L.) DC.

Mimosa pudica. L.

Tephrosia purpurea (L.) Pers.

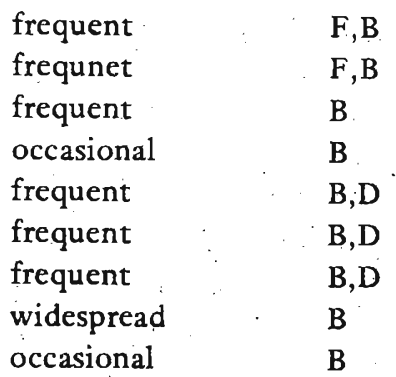


13. GRAMINEAE (POACEAE)

Alloteropsis cimicina (L.) Stapf

Axonopus affinis Chase

Axonopus compressus (Sw.) Beauv.

Coix gigantea Koen. ex Roxb.

Ecbinocbloa colonum (L.) Link.

Ecbinocbloa crus-galli (L.) Beauv.

Echinocbloa frumentacea Link.

Echinochloa stagnina (Retz.) Beauv.

Eleusine indica (L.) Gaertn.

Eragrostis gangetica (Roxb.) Steud.

Eragrostis tenella (L.) Beauv. ex

Roem \& Schult

Eragrostis unioloides (Retz.) Nees ex Steud. Isacbne globosa (Thunb.) Kuntze

Isachne miliacea Roth ex Roem: \& Schult

Iscbaemum indicum (Houtt.) Merr.

Ischaemum muticum $\mathrm{L}$.

Ischaemum rugosum Salisb.

Leersia bexandra. Sw.

Leptochloa chinensis (L.) Nees

Oryza perennis Moench

Oryza rufipogon Griff.

Panicum brevifolium $\mathrm{L}$.

Panicum repens (L.) beauv.

Paspalum commersonii Lam.

Paspalum conjugatum Berg.

Sacciolepis indica (L.) Chase

Sacciolepis interrupta (Willd.) Stapf

Setaria geneculata (Lam.) Beauv.

Sporobolus diandrus (Retz.) Beauv.

14. HYDROCHARITACEAE

Blyxa octandra (Roxb.) Planch. ex Thw.

Ottelia alismoides (L.) Pers.

occasional

$\mathrm{D}, \mathrm{F}$

occasional

D,F

15. HYDROPHYLLACEAE

Hydrolea zeylanica (L.) Vahl

occasional

$\mathrm{F}$ 
16. LAMIACEAE (LABIATAE)

Hyptis capitata Jacq.

Hyptis suaveolens (L.) Poit.

Leucas zeylanica (L.) R. Br.

17. LENTIBULARIACEAE

Utricularia bifida $\mathrm{L}$.

Utricularia reticulata $\mathrm{Sm}$.

18. LOBELIACEAE

Lobelia alsinoides Lam.

occasional

F

19. LYTHRACEAE

Rotala densiflora (Roth ex Roem. \& Schult.) Koehne

frequent

F

20. MARSILIACEAE

Marsilea quadrifolia L.

21. ONAGRACEAE

Ludwigia adscendens (L.) Hara

Ludwigia spp. (decurrens Walt.?)

Ludwigia byssopifolia (G.Don) Exell

Ludwigia perennis $\mathrm{L}$.

22. POLYGONACEAE

Polygonum barbatum L.

Polygonum glabrum. Willd.

23. PONTEDERIACEAE

Monochoria vaginalis (Burm. f.) Kunth

widespread

F,D,B

24. RUBIACEAE

Hedyotis auricularia L.

Knoxia zeylanica L.

Mitracarpuis hirtus (L.) DC.

Oldenlandia corymbosa L.

Spermacoce bispida L.

Spermacoce latifolia Aubl. occasional

widespread

widespread

occasional

frequent

B,D

occasional

$B, D$

F, B

F, B

F, B

F,D
F,B
F,B
F,B

B

B

F

F

F,D

$\begin{array}{ll}\text { widespread } & \text { B } \\ \text { frequent } & \text { B } \\ \text { frequent } & \text { B } \\ \text { frequent } & \text { B } \\ \text { widespread } & \text { B } \\ \text { widespread } & \text { B,F }\end{array}$




Taxon \& Family $\quad$ Occurrence $^{\mathrm{a}} \quad \begin{gathered}\text { Major } \\ \text { Habitat }\end{gathered}$

25. SCROPHULARIACEAE

Bacopa monnieri (L.) Pennell

Dopatrium junceum (Roxb.) Buch-Ham.

$\begin{array}{ll}\text { frequent } & \text { F,B } \\ \text { widespread } & \text { F } \\ \text { widespread } & \text { F } \\ \text { frequent } & \text { F,D } \\ \text { occasional } & \text { F,D } \\ \text { widespread } & \text { F,B,D } \\ \text { widespread } & \text { F,B } \\ \text { frequent } & \text { F,B } \\ \text { widespread } & \text { F,B,D } \\ \text { frequent } & \text { B } \\ \text { widespread } & \text { F,B,D } \\ \text { widespread } & \mathrm{B}\end{array}$

26. SALVINIACEAE

Azolla pinnata: Lam.

Salvinia molesta D.S. Mitchell

$\begin{array}{ll}\text { occasional } & \text { F,D } \\ \text { widespread } & \text { F,D }\end{array}$

27. STERCULIACEAE

Melochia corchorifolia L. widespread B,F

28. TILIACEAE

Corchorus olitorius $\mathrm{L}$.

Triumfetta rbomboidea Jacq.

frequent

B, F

frequent

B

29. XYRIDACEAE

Xyris indica L.

frequent

F,D

$\mathrm{a}_{\text {widespread }}=$ most common and widely distributed; frequent $=$ less common, yet frequently found also with wide distribution; occasional = least common, patchy in appearence.

${ }^{b}=$ Bund $; D=$ Ditch (irrigation canal) $; F=$ Field 


\subsection{Monocotyledonous Weeds}

Table 2 gives the occurrence of the commonest monocotyledonous species in the two districts and their levels of infestation. Species have been listed in the order of abundance. In general, the relative abundance of the major weed species found in the two districts was not dissimilar.

In both districts Fimbristylis miliacea was the most frequently recorded monocotyledonous weed, found growing in $96.5 \%$ of fields sampled in Gampaha and in $97.5 \%$ of fields in Colombo. Where it occurred, $38.7 \%$ of its infestations were at the level of 3 or above, indicating its seriousness as a weed. However, this major weed completed its life-cycle within the first 3-4 months and often before the rice crop matured. Hence, by the time of harvesting the rice, this weed may not be very conspicuous, as it would be earlier on in the growing season.

Isachne globosa was the second most frequent weed. In the Colombo district its occurrence was as high as that of $F$. miliacea, but in Gampaha it occurred at a lower frequency. However, this grass-weed notably had a greater proportion of the heaviest infestations with scores of 3 or above being given to $48.6 \%$ of fields where it occurred.

Two species of the sedge genus Cyperus, namely Cyperus iria L. and Cyperus pilosus Vahl, were the third and fourth ranking monocotyledonous weeds in the two districts, Cyperus iria occurred in $82 \%$ of fields sampled in Gampaha and $88 \%$ of fields in Colombo, while the figures for C. pilosus were $70 \%$ and $98 \%$ respectively for the two districts. Like F. miliacea, C. iria was also found most conspicuously in the early part of the growing season. This weed too completed its life-cycle usually before the rice crop matured, and was not prominent at later stages. Cyperus pilosus, on the other hand, was found to persist longer and also to display noticeable variation with respect to dimensions of leaves, size and colour of inflorescence, etc., as noted by Koyama. ${ }^{5}$

Echinochloa colonum (L.) Link. and Echinochloa crus-galli (L.) Beauv. were both found to be major weeds in the rice-fields surveyed. The former occurred in $68 \%$ of fields sampled in Gampaha and $56 \%$ of fields in Colombo. Echinochloa crus-galli was recorded from $63 \%$ of fields in Gampaha and in $49 \%$ of fields in the Colombo district. Infestations of both weeds were moderate to heavy in the two districts (Table 2).

Monochoria vaginalis (Burm. f.) Kunth occurred in $64 \%$ and $59 \%$ of fields in Gampaha and Colombo districts, respectively. Although these infestations were less severe than those of the above, (scores of 1 and 2 in $90 \%$ of fields where it occurred), $M$. vaginalis too appeared to be a major weed in 


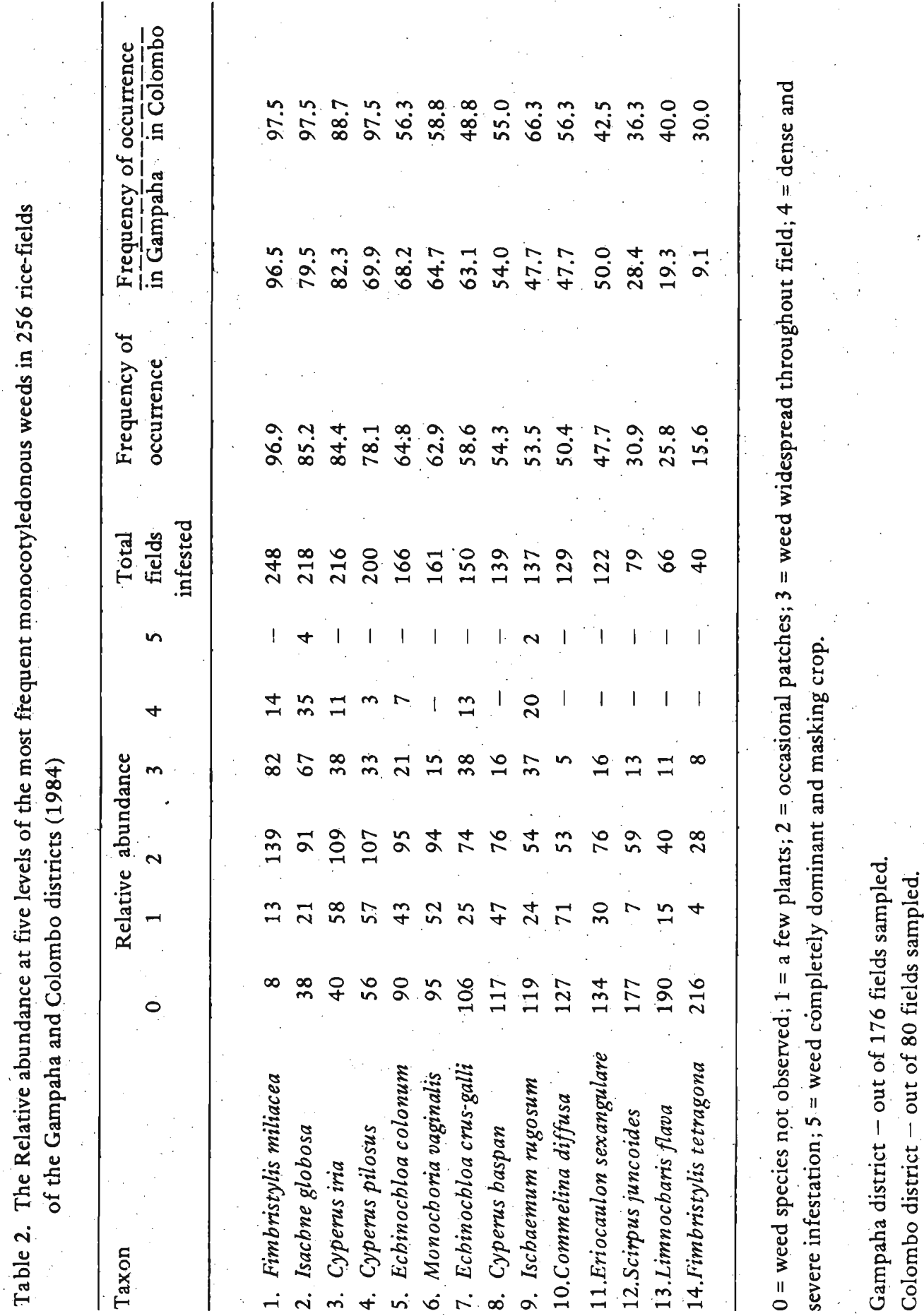


both districts, particularly in the fields fed by irrigation waters.

Cyperus haspan, a species recorded earlier ${ }^{10}$ to be one of the first three major weeds in an all-island survey, occurred only in $54 \%$ of fields sampled in the two districts. Its occurrence in the two districts was not much. dissimilar, and their infestations were also relatively less severe (Table 2).

The occurrence of Ischaemum rugosum Salisb.in the rice-fields is worthy of special mention. Although this grass weed was the 9th most frequent when both districts were considered, its position in the Colombo district was found to be of a higher ranking. It occurred in $66 \%$ of sampled fields in Colombo and was ranked fifth in order of abundance. In Gampaha it occurred in $47 \%$ of fields. In both districts the infestations were fairly heavy. Infestation levels of 3,4 or 5 were recorded from $64 \%$ of fields where it occurred in Colombo, while in Gampaha such heavy infestations were found in $30 \%$ of fields infested with the weed (data not presented). The farmer interviews revealed that $I$. rugosum is a species that appears to be rapidly becoming a major threat to rice cultivation. According to most farmers this weed has already achieved a greater prominence than Cyperus, Isachne, Fimbristylis or Echinochloa species in terms of a need for weed control, Many expressed the view that $I$. rugosum was not considered so important 10-20 years ago, suggesting that its present abundance may have been achieved over a relatively short period of time.

Among other monocotyledonous species found in the rice-fields of the two districts, the following also occurred at fairly high frequency: Commelina diffusa Burm. f., Eriocaulon sexangulare L., Scirpus juncoides Roxb., Limnocharis flava (L.) Buchen., Fimbristylis tetragona R.Br., Fimbristylis dichotoma (L.) Vahl, Eleocharis dulcis (Burm.f.) Trin. ex Hensch., Paspalum commersonii Link., Sacciolepis indica (L.) Chase and Kyllinga brevifolia Rottb.

\subsection{Dicotyledonous Weeds}

The occurrence of the most frequent dicotyledonous weeds in the rice-fields sampled and their levels of infestation are given in Table 3. Fifty-two dicotyledonous weed species were recorded from the rice-fields in the present survey. However, only a few species were recorded as of high infestation levels and abundance.

Ludwigia hyssopifolia (G.Don) Exell was by far the most frequently recorded dicotyledonous weed. Its occurrence in the two districts was very similar. All fields sampled in the Colombo district (100\%) and $92 \%$ of fields in the Gampaha district had this weed. Infestations of $L$. hyssopifolia were also found to be heavy with scores of 3 or higher recorded for $37 \%$ of fields 


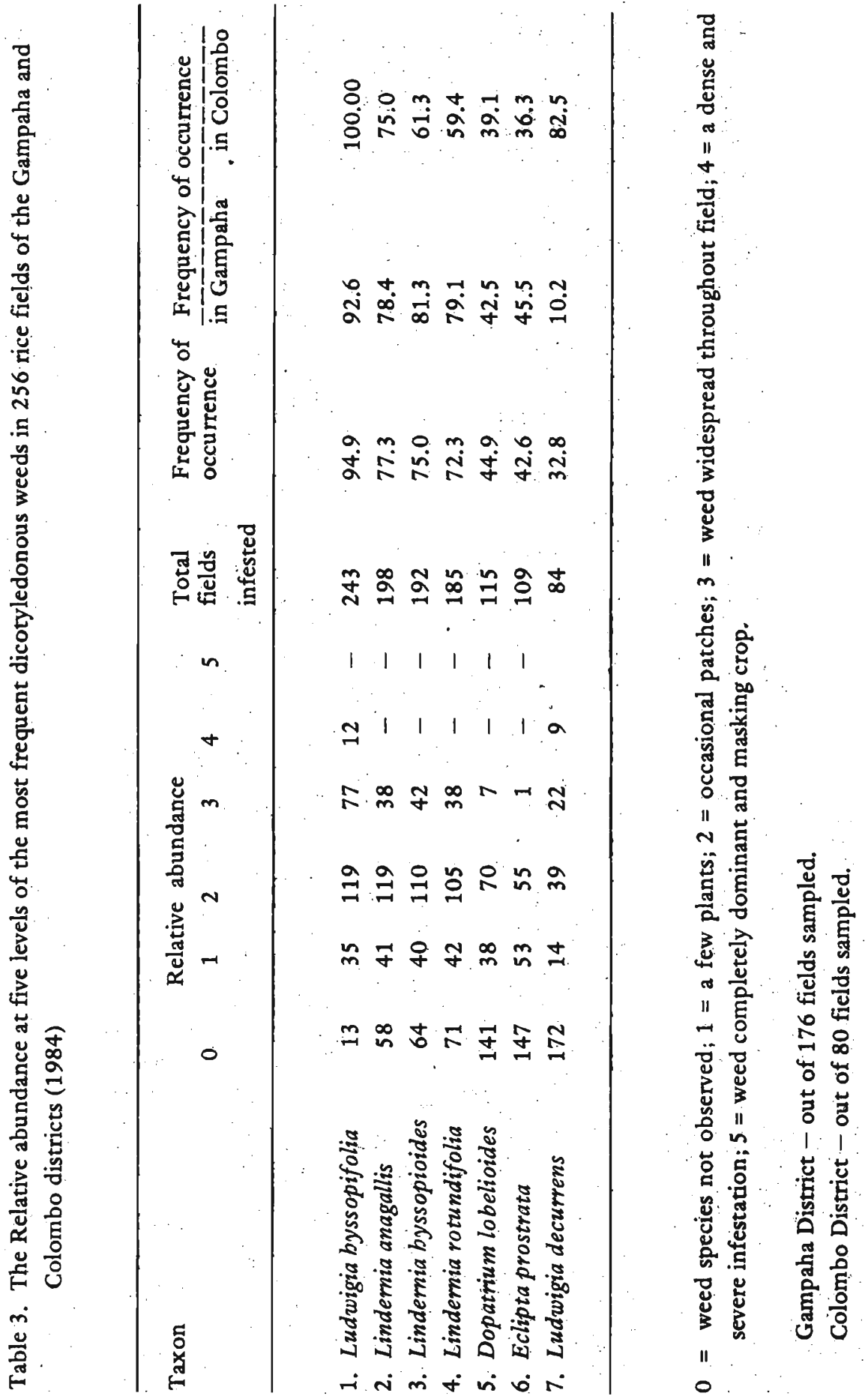


in which it was recorded from both districts. A seccond species of Ludwigia,

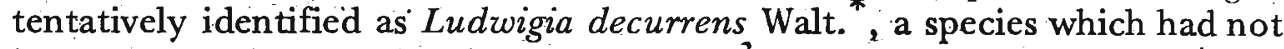
been previously recorded from Sri Lanka, ${ }^{3}$ was also found to occur very commonly, particularly in the Colombo district. It was recorded from the Gampaha district in only about $10 \%$ of fields sampled, thus indicating a major difference in the geographical distribution of the weed. Where it occurred in the Colombo district, infestation levels were high with scores of 3 or higher being recorded for $45 \%$ of the sampled fields (data not presented).

Three species of Lindernia, namely Lindernia anagallis (Burm. f.) Pennell, Lindernia hyssopioides (1.) Haines and Lindernia rotundifolia Alston, were found at high frequency in both districts. However, these infestations were in general less severe than those of the Ludwigia hyssopifolia (Table 3).

Other common dicotyledonous weeds found growing in the rice-fields of the two districts included the following: Dopatrium lobelioides(Retz.) Benth., Dopatrium junceum (Roxb.) Ham., Eclipta prostrata (L.) L., Limnophila repens (Benth.) Benth., Limnophila aquatica (Roxb.) Alston, Lindernia pusilla (Willd.) Boldingh., and Utricularia reticulata Smith.

The distribution of the most frequent dicotyledonous weeds in the two districts was found to be wide and generally uniform, except in the case of the second species of Ludwigia stated earlier. In the Colombo district this weed was found to be regarded as troublesome; but it was clear from the farmer interviews that they made very little distinction between the unidentified* Ludwigia spp. and the more widespread L. hyssopifolia. The farmer interviews also revealed that apart from the Ludwigia species, dicotyledonous weeds cause very little concern to them.

\subsection{Weed Flora of Rice-field bunds}

The weeds found on the rice-field bunds were mainly a fair number of the semi-aquatic species recorded from within the fields and other species which were more terrestrial in nature (Table 4).

The commonest monocotyledonous weeds found on the bunds were: Isachne globosa, Eragrostis unioloides. (Retz.) Nees ex Steud, Fimbristylis miliacea, Cyperus pilosus, Panicum repens L., Commelina diffusa, Paspalum commersonii and Cyperus iria.

The occurrence of $E$. unioloides and $P$. repens was limited to the bund habitat only and their infestations were heavy with scores of 3 or above - This plant species is in the process of being recorded by the author as a new species for Sri Lanka, in a later issue of the J. Natn. Sci. Coun. Sri Lanka. 


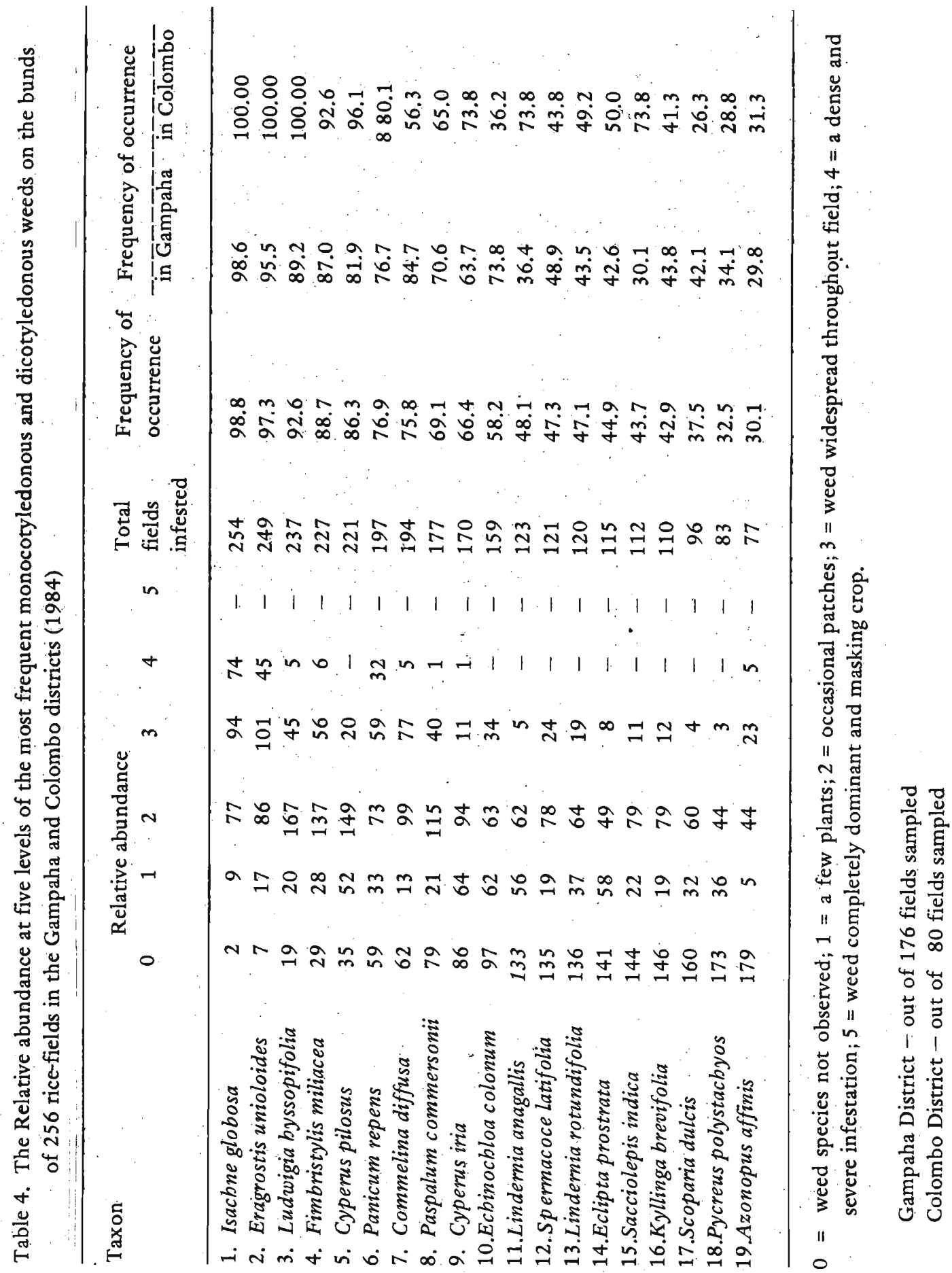


recorded for $58.6 \%$ and $46.2 \%$ of fields where they occurred, respectively: Isachne globosa was the most frequent weed found on bunds in both districts (Table 4) and its infestations were usually heavy with scores of 3 or higher being given to $65.6 \%$ of fields in which the weed occurred in both districts. Other monocotyledonous species found at high frequency on the bunds included: Echinochloa colonum, Ischaemum rugosum, Ischaemum muticum L. (Schaemum indicum Houtt.) Merr., Sacciolepis indica, Kyllinga brevifolia, Pycreus polystachyos (Rottb.) . Beauv. and Axonopus affinis Chase.

Several dicotyledonous semi-aquatics were also commonly found as potential weeds on the bunds. Ludwigia hyssopifolia was the major dicotyledonous weed found growing on bunds, and was recorded from $92.6 \%$ of sampled fields. Infestations of $L$. hyssopifolia on bunds were usually heavy with scores of 3 or higher being given to $21 \%$ of fields in which it occurred. Lindernia spp., Eclipta prostrata, Scoparia dulcis L., Alternanthera sessilis (L.) DC., Leucas zeylanica (L.) R.Br., Hedyotis auricularia L. and Sphaerathus indicus L. were common dicotyledonous semi-aquatic weeds found on the bunds.

In addition, many cosmopoliton and terrestrial weeds were also recorded from the bund habitat. These appeared to have spread to the ricefields from nearby habitats, roadsides and home-gardens. Such species included: Ageratum conyzoides L., Vernonia cinerea (L.) Less., Euphorbia hirta L., Desmodium heterocarpum (L.). DC., Desmodium triflorum (L.) DC., Desmodium heterophyllum (Willd.) DC., Alyssicarpus vaginalis DC., Mitracarpus hirtus (L.) DC., Spermacoce latifolia Aubl., Knoxia zeylanica L., Hyptis suaveolens (L.) Poit, Melochia corchorifolia L. and Triumfetta. rhomboidea Jacq.

\section{Conclusions}

It was evident from the survey data that monocotyledonous weeds constitute the major rice-field weeds in the two districts studied. Presently they appear to be the most frequent and widespread. Fimbristylis miliacea, Isachne globosa and Cyperus iria were the most abundant rice-field weeds both in terms of frequency of occurrence and levels of infestation. Ludwigia hyssopifolia emerged as the biggest dicotyledonous: weed problem which plagues rice-fields in the two districts studied. A second species of Ludwigia whose identity is yet to be confirmed, was found to occur at high frequency mainly in the Colombo district and spreading rapidly, threatening to become a major weed soon. Many other dicotyledonous weeds occurred in the sampled rice-fields, but these did not pose a major threat to rice culture, requiring control measures. In general, a very rich weed flora was found in 
the fields studied, occurring within the field habitat and on the raised earthen bunds, composed mainly of semi-aquatic and terrestrial plant species.

\section{Acknowledgements}

The author is grateful to the Natural Resources, Energy and Science Authority (NARESA) of Sri Lanka for a research grant (RG/84/B/8) which enabled the present study to be carried out, and to Professors I. Balasuriya, S. Balasubramaniam and R.N. de Fonseka for their encouragement and support.

\section{References}

1. AlsTON, A.H.G. (1931) Handbook to the Flora of Ceylon, Vol. VI (Supplement) Dulau \& Co., London.

2. AMARATUNGA, K.L.D. (1977) Ceylon J. Science (Bio Science), 12(2): 185-190.

3. BANSIL, P.C. (1971) Ceylon Agriculture-A Perspective. Oxford \& IBH Publ. Co.

4. Chandrasena, J.P.N.R. \& Amarasinghe, V.A. (1985) Proc. Sri Lanka Assoc. Advt. Sci., 41: 68 .

5. DASSANAYAKE, M.D. \& FOSBERG, F.R. (eds.) (1980-1985) Revised Handbook to the Flora of Ceylon, Vols. I - V, Amerind Publ., New Delhi.

6. SENARATNA, S.D.J.E. ((1956) The Grasses of Ceylon. Government Press, Ceylon.

7. STATISTICAL ABSTRACTS (1979) Department of Census \& Statistics, Ministry of Plan Implementation.

8. TRIMEN, H. \& HOOKER, J.D. (1893-1900) A Handbook to the Flora of Ceylon, Vol. I-V, Dulau \& Co., London.

9. VELMURUGU, V. (1980) A review of Weed Control in rice. Rice Symposium1980, Department of Agriculture, Peradeniya, Sri Lanka.

10. WEERAKOON, W.L. \& GUNAWARDENA, S.D.I.E. (1983) Rice-field Weed Flora of Sri Lanka. Trop. Agric., 139: 1-14. 